\title{
Biological Influence on the Mobility of Metals from Mine Tailing Dump Located in Krugersdorp Area
}

\author{
Ashley H. Munyai ${ }^{1}$, Elvis Fosso-Kankeu ${ }^{2}$, Frans Waanders ${ }^{3}$ \\ School of Chemical and Minerals Engineering, Faculty of Engineering, North-West University, Potchefstroom - South Africa
}

\begin{abstract}
Anthropogenic activities such as mining and smelting of metals ores have increased the prevalence of heavy metals which mobility in the tailing dumps or solid wastes is increased following deposition of the later in the environment.In nature, microbes are involved in weathering of rocks, in the mobilization of metals from minerals,in the reduction and oxidation of metals, and in metal precipitation and deposition.Asix steps sequential extraction method, according to the Tessier method was used to fractionate heavy metals into the following fractions: (F1) water soluble fraction $\left(\mathrm{H}_{2} \mathrm{O}\right),(\mathrm{F} 2)$ exchangeable metals, (F3) easily reducible fraction $\left(\mathrm{CO}_{3}\right)$, (F4) Moderately reducible fraction (Oxide), (F5) metals associated with organic matter and secondary sulphides (organics) and (F6) a residual fraction. The results showed higher concentrations of heavy metals such as Fe, $\mathrm{Pb}$ and $\mathrm{Zn}$, which were dominant in various fractions of the different sampling points (top, middle and bottom of the tailing dump). The DNA sequencing was carried out on tailing samples to identify the microorganisms likely to promote the mobility of metals. Among the host of microorganisms identified, autotrophic species such asLeptospirrillumsp and Sulfobacillus, as well as heterotrophic species such as Bacillussp and Pseudomonasspare those frequently reported in bioleaching processes. The binding groups identified by FTIR attest of the presence of organic matters which are likely to be involved in the entrapment of metals in the organic fraction of the tailing dumps. With most of the metals being attached to the exchangeable and the organic fractions of the tailing dumps, coupled with the presence of active microorganisms, the susceptibility of metal release from the tailings is more probable overtime.
\end{abstract}

Keywords: Tailing dumps, sequential leaching, microorganisms, mobility of metals, pollution

\section{Introduction}

Human activities such as mining, and smelting of metal ores have increased the prevalence and occurrence of heavy metal contamination of the earth`s surface [1].

Mining activities usually produce many types of mine wastes, which include mine tailings, waste rock and slag [2]. Mine tailings are finely crushed rock particles and mineral wastes remaining after extraction of valuable components that are produced and deposited in slurry form on tailing dumps [3]. Mine tailings can be referred to as a mine soil. Wastes from gold mines constitute the largest single source of waste and pollution in South Africa as can be seen from the Witwatersrand mining basin, which is the world largest gold and uranium mining area [4]. Wastes generated by the mining industry contain high concentrations of metals and metalloids which can be mobilized, resulting in leaching of such metals into groundwater and surface water. Most of these heavy metals are highly toxic and are not biodegradable [5].The presence of high concentration of toxic metals make the tailings among other mine wastes the largest environmental impactand the most susceptible to wind dispersal and water erosion, which are the main mechanisms for the loss of metals from mine tailings [6].The mine wastes contain large amounts (between 10 and 30kg/ ton) of sulphide minerals, such as pyrite $\left(\mathrm{FeS}_{2}\right)$, which are prone to generate acid mine drainage (AMD). AMD is generated when erosion of poorly managed tailings dumps occurs, and the tailings subsequently washed away by rain water [3].For example, enormous amounts of mine tailing found in the abounded mines in the Krugersdorp area have contaminated the soil and groundwater in that area, assuch mine wastes have eroded and mobilized to the bottom of the dump and neighboring area. The mine tailing contamination of soil and water might lead to a high level of toxicity from heavy metalssuch as $\mathrm{Zn}, \mathrm{As}, \mathrm{Pb}, \mathrm{Ni} \mathrm{Cr}$ and $\mathrm{Cu}$ which are mostly found in contaminated areas. Arsenic is commonly found in high concentrations in mine tailings because of its natural occurrence in $\mathrm{Ag}$ and $\mathrm{Au}$ ores and the surrounding bedrock[7].Some studies have investigated the availability of metals in the soil and tailings; according to the study reported by $\mathrm{Wu}$ et al.[8],an estimation of metal availability is more useful, since it is related to specific bioavailability, reactivity and mobility. The mechanisms concerning metal accumulation in soil lead to the existence of five major geochemical forms [8]): (i) exchangeable; (ii) bound to carbonate phase; (iii) bound to iron manganese oxides; (iv) bound to organicmatter; and (v) residual metal phase.

Biological influence processes can contribute to a large extent to future technologies which includes mine wastes treatment; in this case the microorganisms are accepted to be the natural way of solving the environmental issues [9]. According to suchstudies microorganisms can influence the mobility of the metals in the mine waste in several ways[10].Microorganisms can be able to mobilize metals through autotrophic and heterotrophic leaching, chelation by microbial metabolites and siderophores and methylation, which can results in volatilization [11].

Most naturally occurring bacteria and fungi accomplish numerous physiologically important reactions that enable them to grow and reproduce [12].Mineralytic effects of bacteria and fungi on minerals are based on four mechanisms namely: (i) acidolysis, (ii) complexolysis, (iii) redoxolysis, and (iv) alkylation [9,12]. Microorganisms are able to mobilize metals through the following processes: Formation of organic and inorganic acids (proton formation), excretion of complexing agents (ligand formation), oxidation and reduction reactions [12]. The organic acids are produced by heterotrophic microorganisms, whereas the inorganic acids are produced by autotrophic organisms. The autotrophic microorganisms 


\section{International Journal of Science and Research (IJSR) \\ ISSN (Online): 2319-7064 \\ Index Copernicus Value (2013): 6.14 | Impact Factor (2015): 6.391}

require atmospheric $\mathrm{CO}_{2}$ as a carbon source and obtain energy for growth from the process of oxidizing ferrous $\left(\mathrm{Fe}^{2+}\right)$ to ferric $\left(\mathrm{Fe}^{3+}\right)$ which creates acidic conditions favorable for metal removal from soil [13]. Autotrophic bacteria can also be called sulphur-oxidizing bacteria, as are capable of oxidizing the metal sulphides to sulphates and thus releasing the metals in cases where respective sulphates are soluble [14]. Those sulphur oxidizing bacteria are considered to be among the most useful microorganisms for the bacterial leaching of sulphide ores[14]. Non sulphudic ores such as oxides, carbonates and silicates which contain no energy source for chemotrophic microorganisms may however be leached by heterotrophic bacteria and fungi, which require an organic carbon source as a source of energy and carbon for their growth [15].The autotrophic bacteria used in bioleaching process to mobilize metals includeChemolithotrophicbacteria of genus Acidithiobacillus and Thiobacillus, such as T.ferrooxidansand $A$. thiooxidans and thiobacillusthioparus[16,13].The Chemolithotrophic bacteria are also called the acidophilic bacteria. Heterotrophic bacteria includeBacillus licheniformis and Bacillus polymyxa, and fungi species such Aspergillum niger and penicilliumsimplissimum. Fungi species such as PenicilliumsimplissimumandAspergillusnigerare some of eukaryotic bioleaching microorganisms that are applied in metal recovery from the industrial wastes particularly the non sulphides[17,9,12]. The main objectives of this study is to investigate the susceptibility of metals release from tailing dumps with a specific focus on the influence of biological matters on the mobility of metals.

\section{Methodology}

\section{Materials}

Mine tailings were collected from a mine area located in the Krugersdorp, Gauteng, South Africa. Thetailings samples were taken from the top $30 \mathrm{~cm}$ of the surface at 14 locations spread between the top, the middle and the bottom of the dump, using an auger drill. All samples were air dried in the laboratory for 2 days, sieved through $75 \mu \mathrm{m}$ of mesh, homogenized before characterization and sequential leaching analysis, the remaining of samples were kept in plastics bags prior to use in the rest of experiment.

\section{Characterization of mine tailings by XRD, XRF and FTIR}

The mineralogical study of the tailings samples were carried out by means of X-ray diffraction (XRD) analysis. The bulk composition was determined using the powder diffraction method, after grinding and homogenization of the samples to $75 \mu \mathrm{m}$ particle sizes. Non-oriented powders were examined on a Philips X'pert MPD diffractometer, at a power of 1.6 $\mathrm{kW}$ operating at $40 \mathrm{KV}$. Major and trace elements of the tailings were analysed using the X-ray- fluorescence spectrometer (XRF) which was done on the magiX PROSuperQ Version 4. A rhodium (Rh) anode was utilized in the X-ray tube and operated at $50 \mathrm{kV}$ and current $125 \mathrm{~mA}$; at power level of $4 \mathrm{~kW}$. For the identification of the functional groups in the tailings and for the evaluation of the surface activation, the FTIR (Fourier transform infrared) spectroscopy was recorded using the IR-Affinity-IS FTIR spectroscopy from Shimadzu. The resolution was set to a 4 $\mathrm{cm}^{-1}$ and the operational range was $4000-400 \mathrm{~cm}^{-1}$.

\section{Sequential leaching}

The mobility of metals is strongly dependent on their specific chemical forms and methods of binding [18]. Sequential leaching can provide information about the fractionation of metals in the different lattices of the solid sample [18]. To better understand the transportation and retention mechanism of elements, 14 tailings samples were selected for sequential leaching: 6 samples were collected on top of the tailing dump, 5 in the middle and 2 at the bottom of the dump. The binding and chemical state of the metals in the tailings was characterized by a sequential leaching procedure which has six fractions (F1-F6). The leaching method was adapted from that of Tessier et al. (1979; modified) as cited byArwidssonand Allard[19]. Fraction 1 (FI) consisted of water soluble metals. Fraction 2 (F2) consisted of exchangeable metals and/or those soluble in slightly acidic conditions. Fraction 3 (F3) (easily reducible fraction) represents metals bound to short range- order Fe, $\mathrm{Al}$ and $\mathrm{Mn}$ (oxy) hydroxides and poorly-crystallised ferric hydroxylsulfates. Fraction 4 (F4) (moderately reducible fraction) represents metals bound to long-range-order Fe, $\mathrm{Al}$ and Mn (oxy) hydroxides and well-crystallised ferric hydroxysulfates. Fraction 5 (F5) represents metals associated with organic matter and secondary sulphides. Fraction 6 (FVI) consists of metals bound to primary sulphides. The following leaching scheme was used:

Fraction 1.Water-soluble $\left(\mathrm{H}_{2} \mathrm{O}\right)$. One gram of dry tailings was added to $20 \mathrm{ml}$ of water; the mixture was agitated continuously for $15 \mathrm{~min}$ at $20^{\circ} \mathrm{C}$ using a shaker. After shaking the mixture was centrifuged at $1600 \mathrm{rpm}$ for 20 minutes. The supernatant was stored for analysis of released elements using the inductively coupled plasma optical emission spectrometry (ICP-OES). The same procedure of centrifugation and analysis was used in each fraction after shaking.

Fraction 2.Cation exchangeable. The residue from F1 was added to $20 \mathrm{~mL}$ of $1.0 \mathrm{M} \mathrm{NH}_{4} \mathrm{Ac}$ that was adjusted to $\mathrm{pH} 7.0$ with acetic acid; the mixture was agitated continuously for 1 h at $20^{\circ} \mathrm{C}$.

Fraction 3.Carbonates and hydroxides $\left(\mathbf{C O}_{3}\right)$. The residue from $\mathrm{F} 2$ was added to $20 \mathrm{~mL}$ of $1.0 \mathrm{M} \mathrm{NH}_{4} \mathrm{Ac}$ that was adjusted to $\mathrm{pH} 5.0$ with acetic acid; the mixture was agitated intermittently for $5 \mathrm{~h}$ at $85^{\circ} \mathrm{C}$.

Fraction 4.Hydrous oxides of $\mathrm{Fe}$ and $\mathrm{Mn}$ (oxide). The residue from $\mathrm{F} 3$ was added to $20 \mathrm{~mL}$ of $0.043 \mathrm{MNH}_{2} \mathrm{OH}-$ $\mathrm{HCl}$ in $25 \%(\mathrm{v} / \mathrm{v})$ acetic acid; the mixture was agitated intermittently for $5 \mathrm{~h}$ at $85^{\circ} \mathrm{C}$.

Fraction 5.Labile organics and amorphous metal sulphides (organic). The residue from F4 was added to 12 $\mathrm{mL}$ of $0.02 \mathrm{M} \mathrm{HNO}_{3}$ and $30 \% \mathrm{H}_{2} \mathrm{O}_{2}(3: 5 \mathrm{v} / \mathrm{v})$ that was adjusted to $\mathrm{pH} 2.0$ with $\mathrm{HNO}_{3}$; the mixture was agitated intermittently for $3 \mathrm{~h}$ at $85^{\circ} \mathrm{C}$, followed by addition of 7.5 $\mathrm{mL}$ of $3.2 \mathrm{M} \mathrm{NH}_{4} \mathrm{Ac}$ in $20 \% \mathrm{HNO}_{3}{ }^{+} 10.5 \mathrm{~mL}$ of distilled water; this mixture was agitated continuously for $30 \mathrm{~min}$ at $20^{\circ} \mathrm{C}$.

Fraction 6.Consolidated organics and metal sulfides, (residual). The residue from 5 was digested in $10 \mathrm{~mL}$ of concentrated $\mathrm{HNO}_{3}{ }^{+} 10 \mathrm{~mL}$ of distilled water.

DNA sequencing

\section{Volume 5 Issue 4, April 2016}




\section{International Journal of Science and Research (IJSR) \\ ISSN (Online): 2319-7064 \\ Index Copernicus Value (2013): 6.14 | Impact Factor (2015): 6.391}

Fresh samples from the abounded mine in Krugersdorp area was used for DNA sequencing. The samples were divided into 3 according to the site of collection as follows: top, middle and bottom of the dump. Genomic DNA was extracted from $1 \mathrm{~g}$ of each of the 14 tailings samples using ZR soil microbe DNA Mini Prep Kit ${ }^{\mathrm{m}}$ according to the manufacturer`s instruction. DNA concentrations were determined spectrometrically with a Nano-Drop spectrophotometer (Thermo scientific). Then extracted DNA samples were sent to a commercial biotechnical laboratory for sequencing using Next Generation Sequencing (NGS)

\section{Determination of Organic Carbon}

1) The organic carbon in the tailings was determined by the use of the Walkley-Black chromic acid wet oxidation method. The moisture content of the air-dry tailings which has been ground to pass a $75 \mu \mathrm{m}$ sieve was determined. A mass of $2 \mathrm{~g}$ of tailing was weighed accurately into a dry tared $250 \mathrm{~mL}$ conical flask to determine the organic carbon content.

2) $10 \mathrm{~mL}$ of $1 \mathrm{~N} \mathrm{~K}_{2} \mathrm{Cr}_{2} \mathrm{O}_{7}$ was accurately added and the flask swirled gently to disperse the soil in the solution. 20 $\mathrm{mL}$ concentrated $\mathrm{H}_{2} \mathrm{SO}_{4}$ was added, directing the stream into the suspension. The flask was swirled immediately until the tailing and the reagent were mixed. A thermometer was inserted in the flask which was heated on a hot plate while swirling the flask and the contents, until the temperature reached $135^{\circ} \mathrm{C}$.

3) To cool the flask slowly, it was set aside in a fume cupboard. Two blanks (without soil) were run in the same way to standardize the $\mathrm{FeSO}_{4}$ solution.

4) When cooling the mixture in the flask (for 20 minutes), it was diluted to $200 \mathrm{~mL}$ with deionized water and preceded with the $\mathrm{FeSO}_{4}$ titration using a "ferroin" indicator. The ferroin titration was conducted as follows:

\section{"Ferroin" Titration}

3 or 4 drops of Ferroin indicator was added and titrated with $0.4 \mathrm{~N} \mathrm{FeSO}_{4}$. As the end point approached, the solution took on a greenish colour and then changed to a dark green. At this point, the ferrous sulphate was added drop-by-drop until the colour changed sharply from blue-green to reddish-grey. When the end point was overshot, 0.5 or $1.0 \mathrm{~mL}$ of $1 \mathrm{~N}$ $\mathrm{K}_{2} \mathrm{Cr}_{2} \mathrm{O}_{7}$ was added and the end point was re-approached drop-by-drop. For the extra volume added, it was corrected for. When over $8 \mathrm{~mL}$ of the $10 \mathrm{~mL}$ dichromate was consumed, the determination was repeated with a smaller tailing sample.

\section{Results and Discussion}

\section{Characterization of mine tailings \\ $X R D$}

The mineralogical composition of the 14 representative samples used in this study is summarized in Table 1 . The mineralogical composition of tailing samples from the Krugersdorp mining area was determined by X-ray diffraction (XRD). The XRD pattern showed the dominance of quartz $\left(\mathrm{SiO}_{2}\right)$ minerals in the top and middle of the tailing dump, while other minerals, such as iron catena-silicate \&ferrosilite, sillimanate, and aluminium iron (III) oxide were only detected in high concentration in few samples. A similar trend about the dominance of quartz in the tailings was reported in the study by Novhe et al.[20].

Table 1: Mineralogical composition of tailing samples

\begin{tabular}{|c|c|c|c|c|c|c|c|c|c|c|c|c|c|c|}
\hline \multirow[b]{2}{*}{ Minerals } & \multicolumn{14}{|c|}{ Weight percentage in each sample } \\
\hline & 1 & 2 & 3 & 4 & 5 & 6 & 7 & 8 & 9 & 10 & 11 & 12 & 13 & 14 \\
\hline Quartz & 84.8 & & - & 91 & 79 & 85 & 92.3 & & & 97 & 73.2 & 91 & - & - \\
\hline Iron catena-silicate, ferrosilite & - & 96 & - & - & - & - & - & - & - & - & - & - & - & - \\
\hline Aluminium iron(III) oxide & - & - & - & - & - & - & - & 60 & - & - & - & - & - & - \\
\hline Sillimanite & - & - & - & - & - & - & - & - & - & - & - & - & 85 & - \\
\hline Dialuminum silicate oxide, kyanite & - & - & 95 & - & - & - & - & - & - & - & - & - & - & - \\
\hline Dicalcium silicate & - & - & - & - & - & - & & - & - & - & - & - & - & 87 \\
\hline
\end{tabular}

\section{$X R F$}

The major, minor and trace elements were determined by using XRF analysis, represented in Table 2. $\mathrm{SiO}_{2}$ is the dominant oxide in all samples collected from the Krugersdorp mining area, which ranges from $40.49 \%$ to $89.15 \%$. This confirms the result obtained using the XRD technique. $\mathrm{SiO}_{2}$ was also found by others to have dominion over other oxides in mine tailings [20]. Heavy metals such as $\mathrm{Al}, \mathrm{Fe}, \mathrm{Cr}, \mathrm{Ni}, \mathrm{Zn}, \mathrm{Cu}, \mathrm{As}, \mathrm{Pb}$ and $\mathrm{Co}$ were also identified in the tailings samples; however, only $\mathrm{Cr}, \mathrm{Fe}, \mathrm{Pb}$ and $\mathrm{Zn}$ were present in almost all the samples and were therefore considered as main focus in the rest of the study.
Table 2: Major and trace elements in tailing samples

\begin{tabular}{|c|c|c|c|c|c|}
\hline \multirow{2}{*}{ Samples } & \multicolumn{5}{|c|}{ Mass \% } \\
\cline { 2 - 6 } & $\mathbf{C r}_{\mathbf{2}} \mathbf{O}_{3}$ & $\mathbf{F e}_{2} \mathbf{O}_{3}$ & $\mathbf{P b O}$ & $\mathbf{Z n O}$ & $\mathbf{S i O}_{2}$ \\
\hline 1 & 0.1 & 7.08 & 0 & 0.01 & 69.7 \\
\hline 2 & 0.05 & 2.68 & 0.02 & 0 & 81.4 \\
\hline 3 & 0.08 & 3.03 & 0 & 0 & 78.1 \\
\hline 4 & 0.07 & 1.79 & 0 & 0.01 & 80.7 \\
\hline 5 & 0.08 & 2.9 & 0.01 & 0.01 & 78 \\
\hline 6 & 0.06 & 2.7 & 0.07 & 0.01 & 78.6 \\
\hline 7 & 0.11 & 1.89 & 0.02 & 0.01 & 86.5 \\
\hline 8 & 0.11 & 5.58 & 0.03 & 0.01 & 72.8 \\
\hline 9 & 0.08 & 38.2 & 0.33 & 0.03 & 40.5 \\
\hline 10 & 0.06 & 6.18 & 0.21 & 0.01 & 69.7 \\
\hline 11 & 0.02 & 10.5 & 0.04 & 0 & 70.2 \\
\hline 12 & 0.07 & 6.76 & 0 & 0.01 & 75.3 \\
\hline 13 & 0.05 & 1 & 0 & 0 & 89.2 \\
\hline 14 & 0.07 & 7.24 & 0 & 0.1 & 42 \\
\hline
\end{tabular}




\section{International Journal of Science and Research (IJSR) \\ ISSN (Online): 2319-7064}

Index Copernicus Value (2013): 6.14 | Impact Factor (2015): 6.391

FTIR

The FTIR results for the samples taken at the top of the dump (S1-S7), middle (S8-S12) and bottom of the tailing dump (S13-S14) are shown in Figure 1A, B and C respectively. Generally, the spectra which depict the top and the middle of the dump were very similar and exhibited same peak pattern. However most samples from the top of the dump do not show the broad peak identified in the samples from the middle of the dump, which is about $2400 \mathrm{~cm}^{-1}$ due to stretching hydrogen bonded $\mathrm{OH}$ group. Samples from the middle of the dump also exhibit a peak which range between 1609.85 and $1424.70 \mathrm{~cm}^{-1}$ which corresponds to the $\mathrm{H}-\mathrm{CH}$ bond, as well as a peak in the range $1124-1000 \mathrm{~cm}^{-1}$, which is attributed to C-O stretching, i.e esters and ethers. Samples from the bottom of the dump reveal peaks at $3029.03-2917.65 \mathrm{~cm}^{-1}, 2393.33-2240.33 \mathrm{~cm}^{-1}$ and $1083.31-1014.25 \mathrm{~cm}^{-1}$, which are attributed to $\mathrm{H}-\mathrm{C}-\mathrm{H}$ asymmetric and symmetric/ $\mathrm{H}-\mathrm{C}-\mathrm{H}$ asymmetric stretching, $\mathrm{C}=\mathrm{H}-\mathrm{H}$ asymmetric , $\mathrm{C} \equiv \mathrm{N}$ and $\mathrm{C}-\mathrm{O}$ stretching. All the groups identified on the spectra are able tobindto metals. The organic matters normally are likely to complex as a ligand and release the metals. In that regard Brandl and Faramarzi, [9] have explained the mechanism of complexolysis (ligand-induced metal solubilization) in which the microbial formation ofcomplexing or chelating agents leads to an increase of metal mobility, these complexes are formed on the metal surfaces by ligand exchange polarizing bonds and facilitating the detachment of metals from the surface. Although these metals can mobilize or release metals from tailings, the availability of metals in solution can be affected by the binding group identified by FTIR, all the C2 report can bind to the metals and prevent the release of metals. The groups observed by FTIR analysis are similar to the groups causing metal mobility as reported byBrandl and Faramarzi[9], namely carboxyl, sulfonate, phosphate, hydroxylamino or imino residues.
(A)

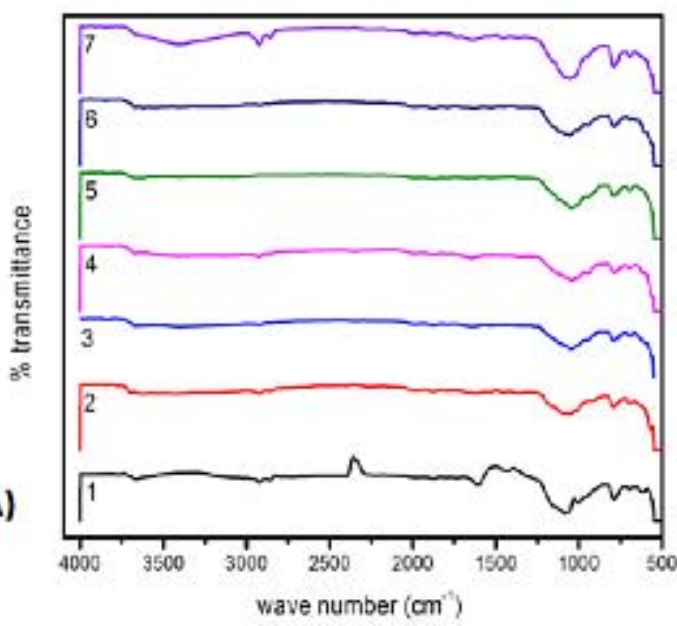

(B)

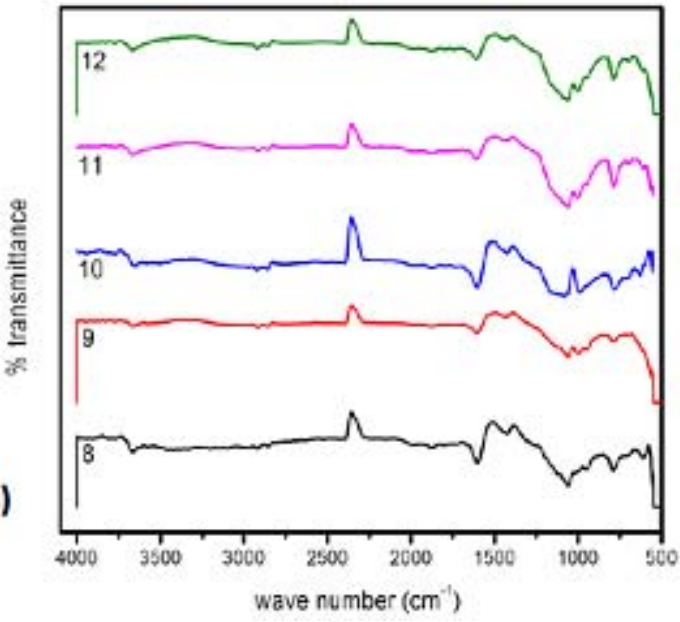

(C)

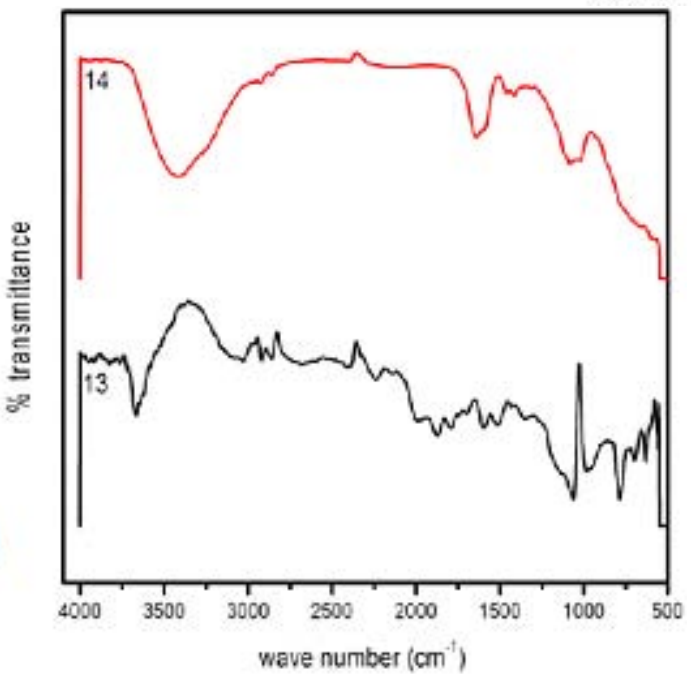

Figure 1: FTIR spectra of (A) top samples 1-7, (B) middle samples 8-12 and (C) bottom samples 13-14 of the tailing dump

Microorganisms in the tailing dumps

In the DNA sequencing results shown in Table 3, the acidophile bacteria of genus Leptospirillum ferroxidans where found in all the three sampling sites and represented $0.14 \%, 0.36 \%$ and $0.01 \%$ of all the microorganisms in samples from the top, middle and bottom of the dump, respectively. The acidophile bacteria of genus Sulfobacillussp was also found in the middle of tailing dumps. According to the literature these microorganisms often occur in dumps of mine waste rockandtailingsfrom sulfide ore processingplants. Acidophiliciron(II)- andsulfuroxidizing bacteria are responsible for the release of sulfuric acid which are able to promote the release of metals from the tailing dumps[21].Heterotrophic bacteria were represented by Bacillussp and Pseudomonassp which are among the bacteria species must likely to degrade the organic matter to form organic acids; these species were found at all the sampling sites. 


\section{International Journal of Science and Research (IJSR) \\ ISSN (Online): 2319-7064 \\ Index Copernicus Value (2013): 6.14 | Impact Factor (2015): 6.391}

Table 3: Selected species from blast output results

\begin{tabular}{|c|c|c|c|c|}
\hline \multirow{2}{*}{$\begin{array}{c}\text { Sampling } \\
\text { Site }\end{array}$} & \multicolumn{2}{|c|}{ Autotrophic bacteria } & \multicolumn{2}{|c|}{ Heterotrophic bacteria } \\
\hline & Species & $\%$ & Species & $\%$ \\
\hline \multirow[b]{2}{*}{ Top } & \multirow[b]{2}{*}{ Leptospirillum } & \multirow[b]{2}{*}{0.14} & Bacillus & 1.6 \\
\hline & & & Pseudomonas & 1.91 \\
\hline \multirow[b]{2}{*}{ Middle } & Leptospirillum & 0.36 & Bacillus & 1.33 \\
\hline & Sulfobacillus & 0.1 & Pseudomonas & 1.1 \\
\hline \multirow[b]{2}{*}{ Bottom } & \multirow[b]{2}{*}{ Leptospirillum } & \multirow[b]{2}{*}{0.01} & Bacillus & 0.06 \\
\hline & & & Pseudomonas & 1.22 \\
\hline
\end{tabular}

\section{Mobility of metals}

The results obtained in the various steps of the fractionation technique are shown in Table 4 . In the water soluble fraction (F1), $\mathrm{Zn}$ is the most abundant metal and ranges between 0$60.7 \%$ for samples taken from the top of tailing dump (S1, S2, S3, S4, S5, S6, S7), whilst it ranges between 0 to $62.5 \%$ for the sample taken from the middle of the dump (S8, S9, S10, S11, S12) and it shows a low percentage for samples collected from the bottom of the dump, in the range between $0-2.7 \%$. The abundance of Zinc in the residual fraction (F6) ranges from 0 to $30.8 \%$ for the tailing samples collected from the top of the tailing dump and for sample taken from the bottom of the dump it ranges from 0 to $23 \%$. The lower recovery from the samples collected at the bottom layer was likely due to the fact that these samples were mostly sulfide minerals, which do not dissolve easily. The recovery percentage of zinc in other fractions was low, which means that the mobility of $\mathrm{Zn}$ in the tailing is much likely to occur in the exchangeable fraction while the rest is more likely to remain in the tailing for a long time. The metals leached in ultrapure acidified water- "water-soluble" fraction (i.e. leaching stage 1) - are relatively labile and thus may be potentially bioavailable [22]. This fraction consists of elements that are easily soluble, e.g. as chlorides and sulphates [22]. This fraction is the most readily available one from the point of view of the environment, and thus the leaching of metals in this fraction is a major environmental concern [22].

The highest recovery of $\mathrm{Pb}$ bound to the carbonate fraction (F3), was found in samples collected at the top of the tailing dump and ranged from $0-85.65 \%$, which was higher as compared to the residual fraction and the other four fractions in which its concentration ranged from 0 to $34.37 \%$. $\mathrm{Pb}$ in the fraction collected at the top of the tailing dump has a relatively higher mobility and potential bioavailability than the residual fraction and the other phases (F4 and F5). The reducible or bound to organic fraction has a higher concentration of $\mathrm{Pb}$ than the other geochemical phases, which means that $\mathrm{Pb}$ is less likely to be release under environmental conditions. According to the XRF results there was no $\mathrm{Pb}$ in the samples collected at the bottom of the dump, which explains why no recovery was achieved through sequential leaching.

Fe was mainly recovered at the bound to organic fraction for the sample taken from the middle of the dump, ranging from 0 to $88 \%$. In this fraction the Fe recovery \% is higher than in the residual and all other fraction for samples collected from the same site, which means that this metal is mostly located in the organic fraction. Metals present in the residual fraction are a measure of the degree of environmental pollution[23]. The higher the metals present in the residual fraction, the lower the degree of pollution [23].

Fe is more abundant if bound to a carbonate fraction (F3) and for the sample found at the top of the dump the Fe recovery \% is higher than in the other fractions for the samples collected from the same site. The Fe recovery \% is high for samples taken from the bottom of the dump in the fraction bound to a carbonate, and ranged from 8.34 to $10.09 \%$. The recovery \% of $\mathrm{Cr}$ is relatively low in all fractions, however the water soluble fraction (F1), exhibits a high concentration for the sample found on top of the dump as the recovery ranges from $0-1.58 \%$. Thus this recovery $\%$ is the highest compared to all the other phases, considering samples collected from the same site. For the samples collected in the middle of the tailing dumpZn was the metal easily removed in all the fractions; however higher recovery of $\mathrm{Zn}$ was achieved in fraction 1 where the recovery percentage ranged between 0 and $62.51 \%$; implying that under environmental conditions, $\mathrm{Zn}$ will be very mobile from the middle layer of the tailings. The order of recovery of the other metals mostly varied according to the specific sites in the middle layer; however, according to the general trend, the following order $\mathrm{Fe}>\mathrm{Pb}>\mathrm{Cr}$ could be considered. The recovery of metals in the samples from the bottom of the tailings was poor compared to the other sites, which furthermore confirms the fact that the refractory structure or mineralogy of the samples from the bottom of the tailings is a limiting factor to the mobility of the metals. It is therefore clear that the oxidation (weathering)of the top surface of the tailing which is more exposed to atmospheric conditions contributes to increase the mobility of metals. 


\section{International Journal of Science and Research (IJSR) ISSN (Online): 2319-7064 \\ Index Copernicus Value (2013): 6.14 | Impact Factor (2015): 6.391}

Table 4: Sequential leaching results showing six fractions in a three sampling sites: Top of the tailing dump (S1-S7), middle of the tailing dump (S8-S12) and bottom \& foot of dump (S13 and S14)

\begin{tabular}{|c|c|c|c|c|c|c|c|c|c|c|c|c|c|c|}
\hline Fractions and elements & \multicolumn{14}{|c|}{$\%$ Recovery of metals per sample } \\
\hline Fraction 1 & 1 & 2 & 3 & 4 & 5 & 6 & \begin{tabular}{|l|}
7 \\
\end{tabular} & 8 & \begin{tabular}{|l|}
9 \\
\end{tabular} & 10 & 11 & 12 & 13 & 14 \\
\hline $\mathrm{Cr}$ & 0.97 & 0.4 & 1.04 & 1.58 & 0 & 0.19 & 0.22 & 0.54 & 7.23 & 2.76 & 0 & 0.45 & 0.98 & 0.08 \\
\hline $\mathrm{Fe}$ & 0.2 & 5.15 & 7.17 & 0.07 & 0.34 & 0.1 & 0 & 2.62 & 20.37 & 0.08 & 0.01 & 0.1 & 0.02 & 0.06 \\
\hline $\mathrm{Pb}$ & 3.59 & 0 & 27.5 & 0 & 0 & 19.91 & 6.85 & 0.93 & 0 & 4.1 & 0.84 & 0 & 0 & 0 \\
\hline $\mathrm{Zn}$ & 60.7 & 0 & 17.14 & 57.18 & 36.7 & 13.37 & 18.35 & 22.77 & 30.81 & 62.51 & 0 & \begin{tabular}{|l|}
57.44 \\
\end{tabular} & 0 & 2.65 \\
\hline Fraction 2 & 1 & 2 & 3 & 4 & 5 & 6 & 7 & 8 & 9 & 10 & 11 & 12 & 13 & 14 \\
\hline $\mathrm{Cr}$ & 0.34 & 0 & 0 & 0.05 & 0.33 & 0 & 0.46 & 0.03 & 0.1 & 0.12 & 0.06 & 0 & 0 & 0.08 \\
\hline $\mathrm{Fe}$ & 0.02 & 0.03 & 0.13 & 0,02 & 0.03 & 0.12 & 0.04 & 0.27 & 2.98 & 0.02 & 3,75 & 9.25 & 0.02 & 0.14 \\
\hline $\mathrm{Pb}$ & 4.19 & 0 & 0 & 0 & 0 & 34.15 & 6.05 & 6.2 & 0 & 0 & 4.2 & \begin{tabular}{|l|}
62.28 \\
\end{tabular} & 0 & 0 \\
\hline $\mathrm{Zn}$ & 10.38 & 0 & 8.34 & 0 & 24.37 & 0 & 7.98 & 11.77 & 0 & 0 & 0 & 0.48 & 0 & 5.31 \\
\hline Fraction 3 & 1 & 2 & 3 & 4 & 5 & 6 & 7 & 8 & 9 & 10 & 11 & 12 & 13 & 14 \\
\hline $\mathrm{Cr}$ & 1.19 & 0.05 & 0.11 & 0 & 0.05 & 0 & 0.89 & 0.1 & 0 & 0.15 & 0.09 & 0.81 & 0.07 & 0.12 \\
\hline $\mathrm{Fe}$ & 0.17 & 0.14 & 20.93 & 8 & 0.04 & 0.14 & 0.23 & 3.21 & 16.85 & 3.48 & 0.03 & 0.09 & 8.34 & 10.09 \\
\hline $\mathrm{Pb}$ & 0.07 & 0 & 85.62 & 0 & 0 & 0 & 0 & 0 & 0 & 14.69 & 2.93 & 0 & 0 & 0 \\
\hline $\mathrm{Zn}$ & 47.91 & 0 & 19.97 & 26.75 & 32.42 & 0 & 9.58 & 8.07 & 5.53 & 11.07 & \begin{tabular}{|l|}
0 \\
\end{tabular} & 40.91 & 0 & 0.81 \\
\hline Fraction 4 & 1 & 2 & 3 & \begin{tabular}{|l|}
4 \\
\end{tabular} & 5 & 6 & 7 & 8 & 9 & 10 & 11 & \begin{tabular}{|l|}
12 \\
\end{tabular} & 13 & 14 \\
\hline $\mathrm{Cr}$ & 0.15 & 0.05 & 0 & 1.02 & 0 & 0.06 & 0.19 & 0 & 0.08 & 0.15 & 0.09 & 0 & 0 & 0 \\
\hline $\mathrm{Fe}$ & 2.21 & 2.64 & 62.11 & \begin{tabular}{|l|}
11.74 \\
\end{tabular} & 49.45 & 0.52 & 0.23 & 5 & 1.52 & 0.03 & 0.85 & 5.56 & 0.09 & 2.5 \\
\hline $\mathrm{Pb}$ & 17.11 & 0 & \begin{tabular}{|l|}
0 \\
\end{tabular} & \begin{tabular}{|l|}
0 \\
\end{tabular} & 0 & 39.4 & 6.25 & 5.32 & 1.46 & 12 & \begin{tabular}{|l|}
3.7 \\
\end{tabular} & 73.04 & 0 & 0 \\
\hline $\mathrm{Zn}$ & 8.7 & 0 & 23.13 & 0 & 50.67 & 3.85 & 11.9 & 0 & 44.26 & 7.46 & 0 & 19.12 & 0 & 3.62 \\
\hline Fraction 5 & 1 & 2 & 3 & 4 & 5 & 6 & 7 & 8 & \begin{tabular}{|l|}
9 \\
\end{tabular} & 10 & 11 & \begin{tabular}{|l|}
12 \\
\end{tabular} & 13 & 13 \\
\hline $\mathrm{Cr}$ & 0.43 & 0.4 & 0.3 & 0.44 & 0.19 & 0.59 & 0.55 & 0.42 & 0.39 & 0.37 & 0 & 0.61 & 0.33 & 0 \\
\hline $\mathrm{Fe}$ & 2.03 & 3.68 & \begin{tabular}{|l|}
7 \\
\end{tabular} & 0.54 & 0.05 & 1.89 & 1.34 & 0.28 & 88.1 & 2.64 & 0.73 & 4.02 & 0.02 & 4.4 \\
\hline $\mathrm{Pb}$ & 8.13 & 0 & 68.02 & 0 & 0 & 0 & 0 & 0 & 0 & 13.82 & 0 & 70.56 & 0 & 0 \\
\hline $\mathrm{Zn}$ & 7.47 & 0 & 10.41 & 0 & 24.41 & 0 & 12.21 & 6.76 & 13.91 & 0 & 0 & 23.92 & 0 & 2.51 \\
\hline Fraction 6 & 1 & 2 & 3 & 4 & 5 & 6 & 7 & 8 & 9 & 10 & 11 & 12 & 13 & 14 \\
\hline $\mathrm{Cr}$ & 0.14 & 0.5 & 0.52 & 0.75 & 0.62 & 0.71 & 0.8 & 0.69 & 0.73 & 0.11 & 0.04 & 0.55 & 0.6 & 0.14 \\
\hline $\mathrm{Fe}$ & 0.2 & 0.85 & 2.43 & 0.41 & 0.96 & 0.39 & 0.54 & 0.16 & 10.16 & 0.34 & 0.12 & 0.23 & 0.11 & 0.47 \\
\hline $\mathrm{Pb}$ & 0 & 0 & 0 & 0 & 0 & 34.37 & 9.78 & 2.07 & 0.38 & 0 & 2.84 & 50.91 & 0 & 0 \\
\hline $\mathrm{Zn}$ & 11.99 & 0 & 14.25 & 24.93 & 30.78 & 2 & 6.43 & 0 & 6.82 & 13.97 & 0 & 23.02 & 0 & 0 \\
\hline
\end{tabular}

Organic carbon $(O C)$ content

The organic carbon results are summarized in Table 5. Organic carbon was present in all samples, i.e. collected on the top of the tailing dump (S1, S2, S3, S4, S5, S6, and S7); in the middle of the dump (S8, S9, S10, S11 and S12) and also at the bottom of the tailing dump (S13 and S14). The top and the middle of the tailing dump contained OC in the range of $0.06 \%$ to $1.44 \%$ while the bottom of the tailing dump exhibited a relatively lower concentration of OC in the range of $0.09 \%$ to $0.18 \%$. However the organic carbon was mainly found in sample S7 which is the sample collected at the top of the dump and S12 which taken at the middle of the dump. The organic carbon acts as the source of nutrients for microorganisms [24], so the presence of organic carbon in all three sampling sites may contribute to the mobility and/or bioavailability of metals, as the microorganisms are capable of degrading the organic carbon to form organic acids which promote the dissolution of metals from tailing dumps[25].
Table 5: Organic carbon (OC), top of the dump (S1-S7), middle of the dump (S8-S12) and bottom of the dump (S13S14)

\begin{tabular}{|c|c|}
\hline Samples site & OC (\%) \\
\hline 1 & 0.19 \\
\hline 2 & 0.2 \\
\hline 3 & 0.06 \\
\hline 4 & 0.09 \\
\hline 5 & 0.06 \\
\hline 6 & 0.06 \\
\hline 7 & 1.44 \\
\hline 8 & 0.13 \\
\hline 9 & 0.09 \\
\hline 10 & 0.08 \\
\hline 11 & 0.06 \\
\hline 12 & 1.44 \\
\hline 13 & 0.09 \\
\hline 14 & 0.18 \\
\hline
\end{tabular}

\section{Conclusion}

The mineralogical structure showed that the top and middle layers of the tailing were mostly made up of oxide minerals while the bottom layer contained sulphide minerals. Metals of commodity values but also with potential of toxicity were found in the tailing dump, irrespective of the layer. It was found that the mineralogical structure of the tailings had a significant impact on the mobility of the metals as they were 


\section{International Journal of Science and Research (IJSR) \\ ISSN (Online): 2319-7064 \\ Index Copernicus Value (2013): 6.14 | Impact Factor (2015): 6.391}

mostly mobile in the top and middle layers, which were made of oxide minerals while they show poor mobility in the samples from the bottom layer, made up of sulphide minerals. The speciation results have shown that most of metals considered in this study were released in large amount from the mobile fractions such as water soluble, carbonate fraction and organic fractions than from the residual fractions, which indicate that these metals are likely to be mobilized in the environment. Autotrophic and heterotrophic microorganisms identified in the tailing dumps have the potential to mobilise metals through mechanisms such as acidolysis or complexolysis; considerable amount of organic carbon was measured in the tailings which can sustain the growth of heterotrophic microorganisms while forming organic acids as byproducts. Binding groups such as $\mathrm{H}-\mathrm{C}-\mathrm{H}, \mathrm{C}=\mathrm{H}-\mathrm{H}, \mathrm{C} \equiv \mathrm{N}$ and $\mathrm{C}-\mathrm{O}$ found in the tailings are likely to be involved in the entrapment of metals in the organic fraction. The susceptibility of metal release from the tailing dumps is therefore likely to be stimulated by chemical and biological mechanisms that can occur naturally in the environment.

\section{Acknowledgements}

The authors are grateful to the sponsor from the North-West University and the National Research Foundation (NRF) in South Africa. Any opinion, findings and conclusions or recommendations expressed in this material are those of the authors and therefore the NRF does not accept any liability in regard thereto.The authors appreciate the contribution of Mr N. Lemmer, and Mr G. Van Rensburg from the NorthWest University; Mr E. Malenga and Ms N. Baloyi from the University of Johannesburg in South Africa.

\section{References}

[1] Rodri'guez L., Ruiz E., Alonso-Azca' J., Rincón J. Heavy metal distribution and chemical speciation in tailings andsoils around a $\mathrm{Pb}-\mathrm{Zn}$ mine in Spain. Journal of Environmental Management.90,1106-1116 (2009).

[2] Lim M., Han G.,Ahn J., You K., and Kim H.Leachability of arsenic and heavy metals from mine tailings of abandoned metal mines. Environ Res Public Health. Nov; 6(11), 2865-2879 (2009).

[3] Ndasi M.B. The accumulation of heavy metals in sedimentary deposits in the Fleurhof and Russel stream dams of the central rand, Johannesburg. MSC Thesis.(2007).

[4] Oelefse S.H.H., Hobbs P.J., Rascher J. and Cobbing J.E.The pollution and destruction threat of gold mining waste on the Witwatersrand - A West Rand case study. (2007).

[5] Bakatula E.N., Cukrowska E.M. and Tutu H. Biosorption of metals from gold mine wastewaters byPenicilliumsimplicissimumimmobilized on zeolite: Kinetic, equilibrium and thermodynamic studies.Czech Geological Survey, ISBN 978-80-7075-781-9 (2012).

[6] Lee S.H., Ji W.H., Lee W.S., Koo N., Koh I.H., Kim M.S., Park J.S. Influence of amendments and aided phytostabilization on metal availability and mobility in $\mathrm{Pb} / \mathrm{Zn}$ mine tailings.Journal of Environmental Management.139: 15-21 (2014).
[7] Kwon J.M., Yang J., Lee S., Lee G., Ham B., BoyanovM.I., Kemner K.M., O'LoughlinE.J.Geochemical characteristics and microbial community composition in toxic metal-rich sediments contaminated with $\mathrm{Au}-\mathrm{Ag}$ mine tailings.Journal of Hazardous Materials. 296: 147-157 (2015).

[8] Wu S.C., LuoY.M., Cheung K.C., Wong M.H.Influence of bacteria on $\mathrm{Pb}$ and $\mathrm{Zn}$ speciation, mobility and bioavailability in soil: A laboratory study. Environmental Pollution.144: 765-773 (2006).

[9] Brandl1 H. and Faramarzi M.A.Microbe-metalinteractions for the biotechnological treatment of metalcontaining solid waste.China Particuology.4: 93-97 (2006).

[10] Ledin M. and Pedersen K. The environmental impact of mine wastes - Roles ofmicroorganisms and their significance in treatment ofmine wastes. Earth-Science Reviews.41: 67-108 (1996).

[11] Gadd G.M. Microbial influence on metal mobility and application for bioremediation. Geoderma.122: 109 119 (2004).

[12] Bosecker K. Bioleaching: metal solubilisation by microorganisms. FEMS Microbiology.20: 591-604 (1997).

[13] Park J., Han Y., Lee E., Choi U., Yoo K., Song Y., Kim $\mathrm{H}$. Bioleaching of highly concentrated arsenic mine tailings by Acidithiobacillusferrooxidans. Separation and Purification Technology.133: 291-296 (2014).

[14] Coto O., Galizia F., Hernández I., Marrero J., Donati E. Cobalt and nickel recoveries from laterite tailings by organic and inorganic bio-acids. Hydrometallurgy.94: 18-22 (2014).

[15] Jain N. and Sharma D.K.Biohydrometallurgy for Nonsulfidic Minerals-A Review. Geomicrobiology Journal. 21:135-144 (2004).

[16] Nguyen V.K., Lee M.H., Park H.J., Lee J. Bioleaching of arsenic and heavy metals from mine tailings by pure and mixed cultures of Acidithiobacillus spp. Engineering Chemistry. 21: 451-458 (2008).

[17] Lee J. and Pandey B.D. Bio-processing of solid wastes and secondary resources for metal extraction - A review. Waste Management.32: 3-18 (2014).

[18] Lu J., Alakangas L., Wanhainen C.Metalmobilizationunderalkalineconditions in ashcoveredtailings. Journal of EnvironmentalManagement. 139: 38-49 (2014).

[19] Arwidsson Z. and Allard B.Remediation of metalcontaminated soil by organic metabolites from fungi II-metal redistribution. Water Air Soil Pollut.207:5-18 (2010).

[20] Novhe N.O., Yibas B., Netshitungulwana R. andLusunzi R.Geochemical and minerological characterization of mine residue deposits in the Komati/Crocodile catchment, South Africa: an assessment for acid/alkaline mine drainage ISBN. 9787-5646-2437-8 (2014).

[21] Korehi H.,Bl. the M.,Sitnikova M.A.,Dold B.and Schippers A. Metal Mobilization by Iron- and SulfurOxidizing Bacteria in aMultiple Extreme Mine Tailings in the Atacama Desert, Chile. Environ. Sci. Technol.47: 2189-2196 (2013). 


\section{International Journal of Science and Research (IJSR) \\ ISSN (Online): 2319-7064 \\ Index Copernicus Value (2013): 6.14 | Impact Factor (2015): 6.391}

[22] Nurmesniemi H., Poykio R., Peramaki P., Kuokkanen T., 2005. The use of a sequential leaching procedure for heavy metal fractionation in green liquor dregs from a causticizing process at a pulp mill.Chemosphere.61: 1475-1484 (2005).

[23] Ashraf M.A., Maah M.J. and Yusoff I. Chemical Speciation and Potential Mobility of Heavy Metals in the Soil of Former Tin Mining Catchment. The Scientific World Journal. (2012).

[24] Edwards J.H., Wood C.W., Thurlow D.L. and Ruf M.E. Tillage and crop rotation effects on fertility status of a Hapludalf soil. Soil Sci. Soc. Am. J. 56:1577-1582 (1999).

[25] Sherene T. Mobility and transport of heavy metals in polluted soil environment.Biological Forum - An International Journal.2(2): 112-121 (2010). 